Anais da Academia Brasileira de Ciências (2019) 91(3): e20180439

(Annals of the Brazilian Academy of Sciences)

Printed version ISSN 0001-3765 / Online version ISSN 1678-2690

http://dx.doi.org/10.1590/0001-3765201920180439

www.scielo.br/aabc | www.fb.com/aabcjournal

\title{
Storage and in vitro germination of orchids (Orchidaceae) seeds from Atlantic Forest - Brazil
}

\author{
CRISTINA R.B. FRANCESCHI ${ }^{1}$, ERIC C. SMIDT ${ }^{2}$, LEILA N. VIEIRA ${ }^{2}$ and LUCIANA L.F. RIBAS \\ ${ }^{1}$ Programa de Pós-Graduação em Botânica, Universidade Federal do Paraná, Av. Coronel Francisco Heráclito \\ dos Santos, 100, Jardim das Américas, Caixa Postal 19031, 81531-980 Curitiba, PR, Brazil \\ ${ }^{2}$ Departamento de Botânica, Universidade Federal do Paraná, Av. Coronel Francisco Heráclito dos \\ Santos, 100, Jardim das Américas, Caixa Postal 19031, 81531-980 Curitiba, PR, Brazil
}

Manuscript received on May 3, 2018; accepted for publication on October 15, 2018

\begin{abstract}
How to cite: FRANCESCHI CRB, SMIDT EC, VIEIRA LN AND RIBAS LLF. 2019. Storage and in vitro germination of orchids (Orchidaceae) seeds from Atlantic Forest - Brazil. An Acad Bras Cienc 91: e20180439. DOI. 10.1590/0001-3765201920180439.
\end{abstract}

\begin{abstract}
The orchid seed banks of Atlantic Forest may be considered a key strategy for the conservation of species threatened with extinction by indiscriminate collection or habitat destruction. The aim of this study was to evaluate the seed viability, to choose the best culture medium for the asymbiotic germination and evaluate germination, after storage for different periods and temperatures for the Brazilian native orchids: Gomesa praetexta (Rchb.f.) M.W.Chase \& N.H.Williams, Gomesa forbesii (Hook.) M.W.Chase $\&$ N.H.Williams, Gomesa recurva R.Br. and Grandiphyllum divaricatum (Lindl.) Docha Neto. Knudson C (KC), Murashige \& Skoog (MS), half-strength MS (1/2 MS macro- and micro-nutrients) and Woody Plant Medium (WPM) culture media were tested for germination. The WPM culture medium was the best for asymbiotic germination of all species evaluated, with high germination percentages and improved seedling development. Seeds of G. divaricatum, G. praetexta, G. recurva and G. forbesii indicated orthodox behavior, with high viability rates after 12 months of storage, being recommended the storage temperature of $-80^{\circ} \mathrm{C}$ for the first three species and $-20^{\circ} \mathrm{C}$ for $G$. forbesii. The protocol developed in the present study was efficient for seed bank storage, in vitro germination and seedling production of $G$. divaricatum and $G$. praetexta, contributing to conservation strategies of these species.
\end{abstract}

Key words: conservation, endangered species, Epidendroideae, Gomesa, Grandiphyllum.

\section{INTRODUCTION}

Orchidaceae is one of largest and most species-rich families of flowering plants, however, their habitats are threatened throughout the world (IUCN/SSC Orchid Specialist Group 1996, Fay 2016). Brazil holds a high species diversity of Orchidaceae, with 2491 species and 221 genera (Flora do Brasil 2020

Correspondence to: Luciana Lopes Fortes Ribas

E-mail: 1lfribas@ufpr.br

ORCid: https://orcid.org/0000-0003-1099-1090 em construção). Among them, the Brazilian native genera Gomesa R. Br. and Grandiphyllum Docha Neto occurs in the Brazilian Atlantic Forest (Flora do Brasil 2020 em construção), which is one of the world's most diverse, but unfortunately, also a highly threatened and fragmented tropical forest biota (Ribeiro et al. 2009). Orchids are highly susceptible to losses in biodiversity and may become critically endangered or extinct due to habitat loss (Cardoso et al. 2016). In addition, the exuberant inflorescences and their uses for ornamentation 
lead to over-collection for economic purposes, a serious threat to many orchid species. This current state of conservation requires the development of integrated conservation approaches, such as ecological and genetic studies, and in situ and ex situ conservation (Swarts and Dixon 2009).

One of the basic problems of ex situ conservation is the seed storage and, subsequently, the plant regeneration from the stored material (Rasmussen et al. 2015). In many species of the Orchidaceae family, seeds tolerate dry storage at $-20^{\circ} \mathrm{C}$ (Seaton et al. 2010). In addition, orchid seeds have the advantage of being small in size (0.05-6 mm) and weight $(0.31-24 \mu \mathrm{g})$, which possibilities the storage of a large number of seeds in a small volume (Seaton et al. 2010). Thus, orchid seed banks may be considered a key strategy for the conservation of valuable genetic resources and possible further re-introduction into the original habitat (Seaton et al. 2010).

In order to germinate in their natural environment, orchid seeds need to encounter particular mycorrhizal fungus and may be reliant upon a different fungus at a subsequent life stage (Seaton et al. 2013). The symbiotic relationship between orchids and fungus plays an essential role in both seed germination and seedling development (Rasmussen et al. 2015). However, most tropical orchids can germinate in sterile culture medium (Rasmussen et al. 2015), and asymbiotic germination represents an ideal system for studying the growth and development of orchid seeds and seedlings (Kauth et al. 2008b). The most common culture media used for orchid germination are Murashige and Skoog (MS; Murashige and Skoog 1962), Knudson C (KC; Knudson 1946), and Vacin and Went (VW; Vacin and Went 1949) (Piria et al. 2008). After germination, orchid protocorms can be subcultured to a plant growth regulator (PGR) supplemented culture medium (with auxin and cytokinin) for protocorm multiplication (Pebam et al. 2016) or to a PGR-free culture medium to promote seedling growth. Activated charcoal is often used in tissue culture to improve plant growth and development (Thomas 2008) and this has been observed for some species of orchids (Santos et al. 2016, Vudala and Ribas 2017).

In this study, we evaluated the seed viability and asymbiotic germination of four Brazilian native orchids, Gomesa praetexta, Gomesa forbesii, Gomesa recurva and Grandiphyllum divaricatum, after storage for different periods and at two temperatures, in order to establish a seed bank. Different culture media were tested for germination and seedling growth. Seedling survival of G. divaricatum and G. praetexta during acclimatization was also evaluate to establish a protocol for the production of seedlings of these species so that in the future they are reintroduced into the natural habitat.

\section{MATERIALS AND METHODS}

\section{PLANT MATERIAL}

Plants of G. recurva and G. forbesii were cultivated in the greenhouse "Frederico Carlos Hoehne" at the Institute of Botany, São Paulo, Brazil, and plants of $G$. divaricatum and $G$. praetexta were cultivated in the greenhouse of Departamento de Botânica da Universidade Federal do Paraná, Paraná, Brazil. Both greenhouses are shaded with $70 \%$ sombrite screen, covered with plastic, without artificial lights and with manual irrigation of the plants once a day.

Capsules were obtained from manual crosspollination by inserting the pollen of one flower into the stigma of the flower of another plant. After 150 days of pollination, four capsules turning from green to yellowish or brown were collected and kept in paper envelopes until they began the dehiscence. Seeds were removed from the capsules and subjected to the drying process according to the Orchid Seed Storage for Sustainable Use (OSSSU), as recommended by Seaton and Ramsay (2005). Seeds were kept in a desiccator containing saturated 
solution of calcium chloride $\left(\mathrm{CaCl}_{2}\right)$ occupying 1/4 of the volume of the desiccator, giving a relative humidity around $30 \%$ at $20^{\circ} \mathrm{C}$, and seed moisture contents of 4 to $6 \%$ for seven days before in vitro germination experiments.

\section{In vitro - GERMINATION}

Dried seeds were submitted to germination procedure in different culture media. Seeds (50 $\mathrm{mg}$ ) were surface sterilized with ethanol $70 \%$ for 30 seconds, followed by $0.75 \%(\mathrm{v} / \mathrm{v})$ sodium hypochlorite solution with $0.1 \%$ Tween ${ }^{\circledR}$ for five minutes. Then, seeds were washed six times with sterile water. The seeds were dried on sterile filter paper and inoculated on Petri dishes containing different culture media: WPM (Lloyd and McCown 1980), MS, MS/2 (half basal salts concentration), and KC. The media were supplemented with $5.6 \mathrm{~g}$ $\mathrm{L}^{-1}$ agar (Vetec Química Fina Ltda, Rio de Janeiro, Brazil) and 3\% sucrose (w/v). pH was adjusted to 5.8 with $\mathrm{NaOH}$ or $\mathrm{HCl} 0.1 \mathrm{~N}$ before the addition of agar. Culture media were sterilized by autoclave for $20 \mathrm{~min}$ at $120^{\circ} \mathrm{C}$. Approximately 500 seeds were inoculated per Petri dish (40 ml; 150 x $20 \mathrm{~mm}$ ) and four replicates per culture medium. Three fields, each containing 100 seeds in each Petri dish, were marked and digital images were analyzed in the computer with the aid of the Photoshop ${ }^{\circledR}$ CS5 5 program. The germination was evaluated after 60 days, being considered germinated the seed that was in the stage of protocorm with shoot apex and the percentage of mortality was also evaluated by counting the necrotic protocorms at various stages of development, after 90 days. Cultures were maintained at $26 \pm 2{ }^{\circ} \mathrm{C} / 18$ $\pm 2^{\circ} \mathrm{C}$ (day/night), under $16 \mathrm{~h}$ photoperiod under fluorescent lamps $\left(40 \mu \mathrm{mol} \mathrm{m} \mathrm{m}^{-2} \mathrm{~s}^{-1}\right)$.

\section{PROTOCORM DEVELOPMENT AND} ACCLIMATIZATION

After 90 days of germination, protocorms of all species were transferred to WPM culture medium, semi-solid (5.6 $\mathrm{g} \mathrm{L}^{-1}$ agar Vetec), supplemented with $1 \mathrm{~g} \mathrm{~L}^{-1}$ activated charcoal and 3\% sucrose $(\mathrm{w} / \mathrm{v})$. Subcultures were performed twice, every 12 weeks, on the same culture medium. In each subculture, 20 seedlings were inoculated per flask ( $6.2 \mathrm{~cm} \mathrm{x} 12.5 \mathrm{~cm}$, with $40 \mathrm{ml}$ of culture medium), with five replicates. Shoot elongation was evaluated after each subculture.

For acclimatization procedures, seedlings of G. praetexta and G. divaricatum were transplanted into a PVC tray with 50 cells $(4 \mathrm{~cm} \times 8 \mathrm{~cm})$ containing a mixture of Eucatex ${ }^{\circledR}$ vermiculite and Plantmax Florestal ${ }^{\circledR}$ substrate (São Paulo, Brazil) (3:1) or a mixture of powdered coconut fiber and Plantmax Florestal ${ }^{\circledR}(1: 1)$. Ten replicates, each one consisting of 5 seedlings, were used for acclimatization. Seedlings were transferred to a greenhouse at room temperature $\left(24 \pm 5^{\circ} \mathrm{C}\right.$ during the day and $20 \pm 5^{\circ} \mathrm{C}$ at night), under a photoperiod of $12 \mathrm{~h}$ and a light intensity of $13 \mu \mathrm{mol} \mathrm{s}{ }^{-1}$. The seedlings were manually irrigated twice a day for ten days and, after this period, once a day. Sixty days after transplanting, the percentage of seedling survival was evaluated.

\section{SEED STORAGE EXPERIMENTS}

Seed drying and storage were performed according to the OSSSU, as recommended by Seaton and Ramsay (2005). Seeds were transferred to small glass tubes full of seeds that were placed within the larger, hermetically sealed jars. Sachets of orange silica gel were included in the larger tubes to act as an indicator for relative humidity maintenance. After this process, the seeds were stored in a freezer at $-20^{\circ} \mathrm{C}$ or $-80^{\circ} \mathrm{C}$ for one, six, and twelve months and used for tetrazolium and germination (TZ) tests.

\section{TETRAZOLIUM TEST}

A small sample of seeds ( $2 \mathrm{mg}$ ) for each temperature and storage period, and also the freshly harvested seeds were preconditioned in a $10 \%$ sucrose solution for $24 \mathrm{~h}$ 
at room temperature. After this period, the solution was drained with a micropipette, $0.1 \%$ tetrazolium Neon $®$ solution was added and the micro-tubes incubated in the dark for $24 \mathrm{~h}$ in a $40^{\circ} \mathrm{C}$ water bath, according to the methodology proposed by Hosomi et al. (2011). After incubation, the tetrazolium solution was discarded and the seeds were placed on a glass plate to be analyzed with the aid of a stereoscopic microscope. The seeds were analyzed and photographed in a Motic SMZ 171 stereomicroscope and viability was evaluated by analysis of digital images taken with a Sony Cyber Shot DSC-P200 camera. Seeds with red carmine color were considered viable. Twelve regions with replicates of 100 seeds were evaluated, totaling 1200 seeds.

\section{SEED STORAGE EFFECT ON SEED GERMINATION}

Approximately 500 seeds were inoculated on WPM culture medium, four fields marked in each Petri dish containing 100 seeds and three replicates per treatment. These fields were always photographed every 15 days, in the same position and the images were analyzed with Photoshop ${ }^{\circledR}$ CS5 program. The germination was evaluated after 60 days, being considered germinated the seed that formed a protocorm with shoot apex.

\section{STATISTICAL ANALYSIS}

Experiments were performed using a completely randomized design, in a 4 x 2 bi-factorial arrangement with four times (zero, one, six and twelve months) and two storage temperatures (- 20 and $\left.-80^{\circ} \mathrm{C}\right)$. Data were submitted to the Bartlett test followed by analysis of variance (ANOVA) and means were compared using Tukey's test at $\mathrm{p}<0.05$ using Assistat ${ }^{\circledR} 7.7$ beta software.

\section{RESULTS}

\section{In Vitro GERMINATION}

Seeds of all species studied presented germination percentages higher than 70\%, except for those sown in KC culture medium (Table I). Seeds cultivated in WPM culture medium presented the higher germination percentage (Figure 1a), followed by MS/2 for G. divaricatum, and G. praetexta (Table I). The seeds of $G$. recurva showed high percentages of germination in WPM, MS, and MS/2, although without statistical difference between the culture media.

However, despite the high germination percentage $(>70 \%)$, MS culture medium (Figure 1b) also presented high protocorm mortality for all species evaluated, ranging from 25 to $49 \%$, while WPM presented very low mortality percentages, varying from 0 to $4 \%$ (Table I). The protocorms cultivated in the $\mathrm{KC}$ medium also had the highest mortality rates ranging from 34 to $38 \%$ for $G$. recurva and $G$. forbesii, respectively, and $50 \%$ for G. praetexta and G. divaricutum.

TABLE I

Germination and mortality percentage for Grandiphyllum divaricatum, Gomesa praetexta, Gomesa forbesii and Gomesa recurva in different saline compositions, after 60 days.

\begin{tabular}{|c|c|c|c|c|c|c|c|c|}
\hline \multirow[b]{2}{*}{ Media culture } & \multicolumn{2}{|c|}{ G. divaricatum } & \multicolumn{2}{|c|}{ G. praetexta } & \multicolumn{2}{|c|}{ G. forbesii } & \multicolumn{2}{|c|}{ G. recurva } \\
\hline & $G^{*}(\%)$ & $\mathbf{M} * *(\%)$ & G $(\%)$ & M (\%) & G (\%) & M (\%) & G (\%) & M (\%) \\
\hline WPM & $94.0^{\mathrm{a}}$ & 0.0 & $90.5^{\mathrm{a}}$ & 3.0 & $92.5^{\mathrm{a}}$ & 4.0 & $78.0^{\mathrm{a}}$ & 2.0 \\
\hline MS & $82.5^{\mathrm{c}}$ & 25.0 & $70.3^{c}$ & 43.0 & $79.0^{\mathrm{b}}$ & 49.0 & $80.5^{\mathrm{a}}$ & 29.0 \\
\hline $\mathrm{MS} / 2$ & $88.0^{b}$ & 6.0 & $81.3^{b}$ & 9.0 & $90.0^{\mathrm{a}}$ & 16.0 & $75.7^{a}$ & 14.0 \\
\hline $\mathrm{KC}$ & $58.5^{\mathrm{d}}$ & 54.0 & $62.5^{\mathrm{d}}$ & 51.0 & $56.5^{\mathrm{c}}$ & 38.0 & $55.5^{\mathrm{b}}$ & 34.0 \\
\hline
\end{tabular}

Medium values followed by the same letter in the same column are not significantly different according to ANOVA and Tukey mean separation test $(\mathrm{p}<0.05)$. ${ }^{*} \mathrm{G}$ : germination $* * \mathrm{M}$ : mortality. 


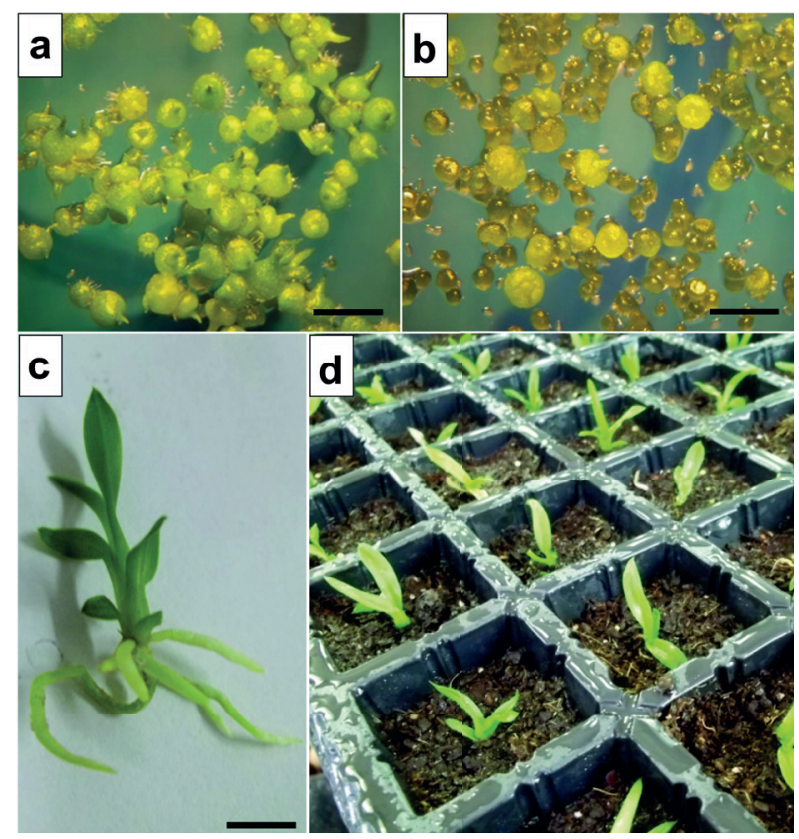

Figure 1 - Grandiphyllum divaricatum seeds germination. Protocorms after 90 days of inoculation: a- in WPM b- in MS culture medium Bar: $2 \mathrm{~mm}$. c- Seedling developed on WPM medium, supplemented with activated charcoal; dAcclimatized plants. Bar: $2 \mathrm{~mm}$. Cell size in tray: $3 \mathrm{~cm}$.

\section{PROTOCORM DEVELOPMENT AND} ACCLIMATIZATION

The protocorms from in vitro germination that were cultivated in WPM culture medium supplemented with activated charcoal resulted in slow growth, with shoots reaching $1 \mathrm{~cm}$ length for $G$. praetexta and $G$. divaricatum, and $0.6 \mathrm{~cm}$ for $G$. recurva and $G$. forbesii, after 16 weeks. However, after the first subculture, plantlets from all four species evaluated presented root development, indicating that even in the absence of auxins, roots development occurred in shoots grown on medium containing activated charcoal.

After the second subculture, the seedlings of $G$. praetexta and $G$. divaricatum showed an average of $3 \mathrm{~cm}$ length after 12 weeks. However, the plants of $G$. recurva and $G$. forbesii presented slower growth than the other species, reaching only $1.5 \mathrm{~cm}$. The elongation response in medium with charcoal may vary according to the species. These slow-growing responses can be explained by the fact that the number of explants per flask was high (20 seedlings) and this may have caused competition for the components of the culture medium. Thus, only $G$. praetexta and $G$. divaricatum seedlings were used for the acclimatization experiments (Figure 1c).

After eight weeks, the plantlets of G. praetexta and $G$. divaricatum showed a high percentage of survival (94\%) in both substrate combinations tested: vermiculite ${ }^{\circledR}$ and Plantmax Florestal $\AA$ (3: 1) or coconut fiber powder and Plantmax Florestal ${ }^{\circledR}$ (1: 1) (Figure 1d).

\section{SEED VIABILITY AFTER STORAGE BY TETRAZOLIUM TEST}

Results of the tetrazolium test indicated that the best temperature and time of storage depended on the species studied. Seeds of $G$. divaricatum showed higher percentages of viable seeds after 6 and 12 months of storage, and the best results occurred with seeds stored at $-80^{\circ} \mathrm{C}$ (Figure 2a). G. praetexta presented a high percentage of viable seeds when freshly harvested $(84.3 \%)$, and also high viability when stored at $-80^{\circ} \mathrm{C}$, indicating that this species can also be stored for up to 12 months (Figure 2b). The best results of G. forbesii occurred with freshly harvested seeds stored for a month, regardless the temperature, and for six months at $-20^{\circ} \mathrm{C}$ (Figure 2c). G. recurva seeds presented a low percentage of viability when freshly harvested $(61.7 \%)$ or when stored up to six months, regardless of storage temperature. For this species, the best results were obtained after 12 months of storage at $-80^{\circ} \mathrm{C}$ (Figure 2d).

\section{EFFECT OF SEED STORAGE ON GERMINATION}

All species evaluated presented similar behavior, with percentages of seed viability between 60 and $70 \%$ when freshly harvested. One-month storage period resulted in a reduction in seed germination, regardless of temperature (Figure 3). 

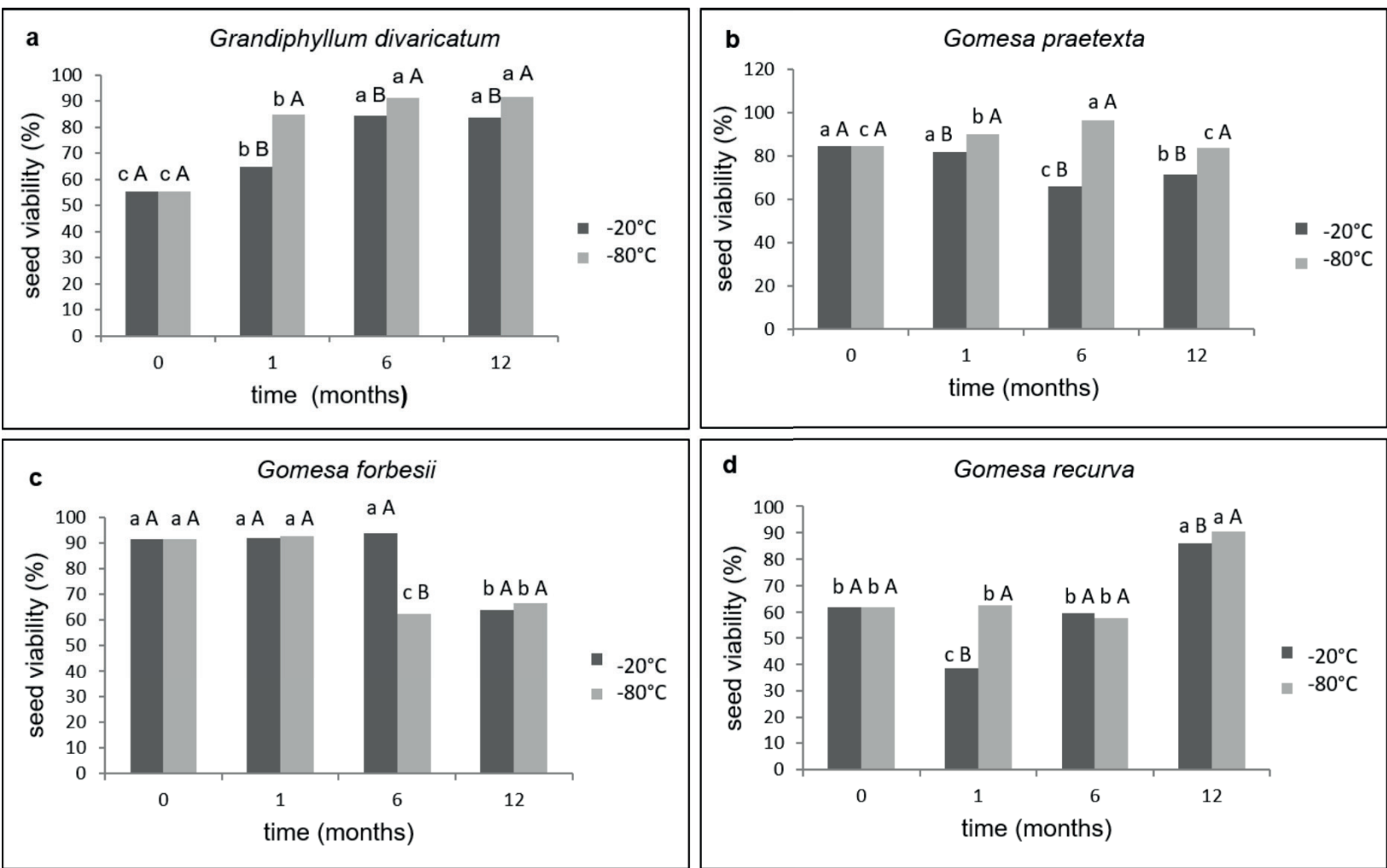

Figure 2 - Seed viability evaluated by tetrazolium test of: a- Grandiphyllum divaricatum, b- Gomesa praetexta, c- Gomesa forbesii and d- Gomesa recurva stored at -20 and $-80^{\circ} \mathrm{C}$ for $0,1,6$ or 12 months.

Lowercase letters indicate differences between storage times in the same temperature and uppercase letters indicate differences between storage temperatures in the same storage time, according to Tukey test $(\mathrm{p}<0.05)$.

For $G$. divaricatum, $G$. praetexta and $G$. recurva, the best results of seed viability were obtained at $-80^{\circ} \mathrm{C}$ after 12 months of storage (Figures 3a, 3b and 3d). However, for G. forbesii it is recommended to store seeds at $-20^{\circ} \mathrm{C}$ (Figure $3 \mathrm{c})$. Seeds of $G$. recurva, $G$. praetexta, and $G$. divaricatum, stored at $-80^{\circ} \mathrm{C}$ for 12 months showed an increase in the percentage of germination.

\section{DISCUSSION}

The germination percentages were affected by the asymbiotic culture media. In general, the best germination percentages for Grandiphyllum divaricatum, Gomesa praetexta, Gomesa forbesii and Gomesa recurva were obtained in WPM (78.0 to $94.0 \%$ ), followed by $\mathrm{MS} / 2$ culture medium $(75.7 \%$ to $90 \%)$. WPM culture medium is a low salt medium as compared to MS, but the principal reason for these responses has been attributed to the total ionic strength of the formulation (Bonga 1985). Similar results were observed for Brasiliorchis picta (Hook) R. B. Singer (Santos et al. 2016) and Hadrolaelia grandis (Lindl. \& Paxton) Chiron \& VP Castro (Vudala and Ribas 2017), in which WPM was also the best for germination and protocorms development.

The salt composition among different culture media varies not only in their concentrations, but also in their available forms, resulting in different responses for each species of orchid (Suzuki et al. 2012). The germination percentages obtained in KC medium were lower than the other media, ranging from 55.5 to $62.5 \%$. In addition, the protocorms cultivated in the $\mathrm{KC}$ medium also had the highest mortality rates ranging from 34 to $38 \%$ for $G$. recurva and G. forbesii, respectively, and 50\% for $G$. 

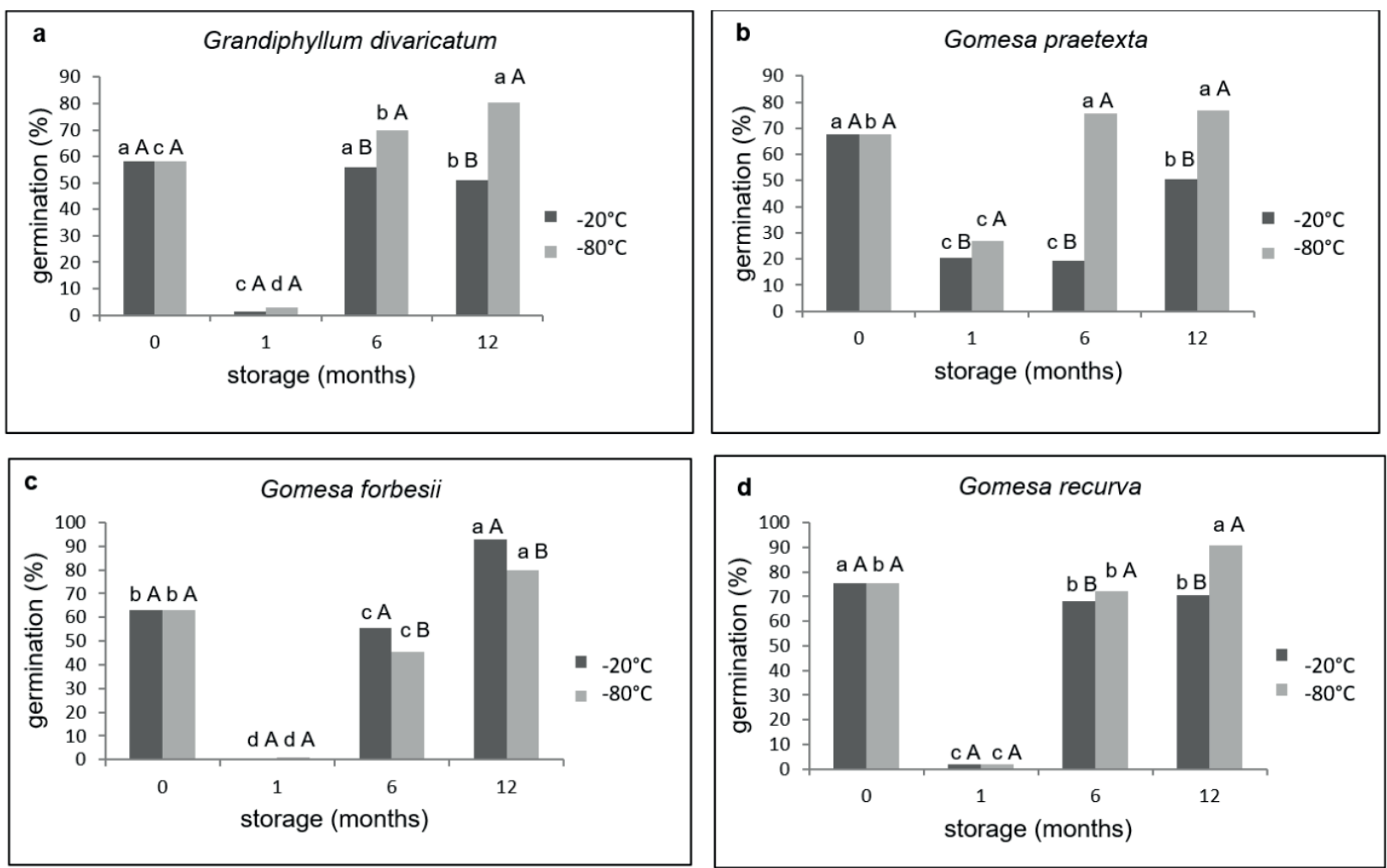

Figure 3 - Percentage of seed germination for a- Grandiphyllum divaricatum, b- Gomesa praetexta, c- Gomesa forbesii, and dGomesa recurva, storage at $-20^{\circ} \mathrm{C}$ and $-80^{\circ} \mathrm{C}$ for $0,1,6$ or 12 months.

Lowercase letters indicate differences between storage times in the same temperature and uppercase letters indicate differences between storage temperatures in the same storage time, according to Tukey test $(p<0.05)$.

praetexta and G. divaricutum. The low germination percentage and high mortality of protocorms observed in $\mathrm{KC}$ culture medium, may be explained by the absence of vitamins and amino acids, which are required for in vitro plant development (Saad and Elshahed 2012). Hosomi et al. (2012) obtained similar results for Cattleya species grown in $\mathrm{KC}$ medium, with protocorms presenting necrosis after 63 days. Similarly, the MS medium was not efficient for the germination and initial development of Habenaria macroceratitis Willd., presenting protocorms mortality before the appearance of the apex shoot (Stewart and Kane 2006). Although Muñoz and Jiménez (2008) reported that the salt composition of $\mathrm{KC}$ and MS are generally the most used formulations for the asymbiotic germination of orchids, they were not efficient for the four species tested in the present study.
G. praetexta and $G$. divaricatum plantlets elongated and developed roots after subculture to medium supplemented with $1 \mathrm{~g} \mathrm{~L}^{-1}$ of activated charcoal. The addition of activated charcoal in the culture media may have contributed to the development of roots as has been reported for other species of orchids (Roy et al. 2011, Vudala and Ribas 2017). According to Pan and Van Staden (1998) and Thomas (2008), the use of charcoal in the culture medium can promote or inhibit in vitro growth, which depends on many factors among them is the adsorption of plant growth regulator and other organic compounds, such as vitamins by the activated charcoal.

The plantlets of $G$. praetexta and $G$. divaricatum showed a high percentage of survival (94\%) in both substrate combinations tested: vermiculite ${ }^{\circledR}$ and Plantmax Florestal ${ }^{\circledR}(3: 1)$ or 
coconut fiber powder and Plantmax Florestal ${ }^{\circledR}$ (1: 1). The commercial substrates tested have properties of high water absorption and retention capacity, porosity and adequate aeration, and their physical and chemical properties were described by Higashikawa et al. (2010) and Klein et al. (2000). These conditions are necessary for the plantlets development of epiphytic orchids during acclimatization, as reported by Chugh et al. (2009). The use of suitable substrates and irrigation care of the seedlings allowed the achievement of high percentages of survival of $G$. praetexta and $G$. divaricatum. Due to the lower price of Plantmax Florestal ${ }^{\circledR}$ (3: 1) in comparison to coconut fiber powder and Plantmax Florestal ${ }^{\circledR}$ (1: 1), we recommend the use of vermiculite and Plantmax Florestal ${ }^{\circledR}$ (3: 1) as commercial substrates for acclimatization of these orchid species. Corroborating our results, high survival rate $(87.5 \%)$ was also observed for the Dendrobium nobile using vermiculite ${ }^{\circledR}$ and Plantmax ${ }^{\circledR}(2: 1)$ (Moraes et al. 2002).

Differences in seed viability after storage at the two temperatures tested $\left(-20^{\circ} \mathrm{C}\right.$ and $\left.-80^{\circ} \mathrm{C}\right)$ varied according to the species. For G. divaricatum, $G$. praetexta and $G$. recurva the best storage temperature was $-80^{\circ} \mathrm{C}$, while for $G$. forbesii it was $-20^{\circ} \mathrm{C}$. The seeds of $\mathrm{B}$. picta also germinated better after storage for 12 months at $-20^{\circ} \mathrm{C}$ showing orthodox behavior (Santos et al. 2016). A similar result was obtained by Hay et al. (2010) when testing temperatures between $23^{\circ} \mathrm{C}$ and $-196^{\circ} \mathrm{C}$ for seed storage of several Australian orchid species. They observed that the temperature of $-18^{\circ} \mathrm{C}$ was the ideal for the maintenance of the seed viability for most species; however, for Pterostylis recurva the best temperature was $-80^{\circ} \mathrm{C}$. Seeds of $G$. recurva, G. praetexta, and G. divaricatum, stored at $-80^{\circ} \mathrm{C}$ for 12 months showed an increase in the percentage of germination. The potential for ultralow-temperature storage (i.e., $-70^{\circ} \mathrm{C}$ to $-196^{\circ} \mathrm{C}$ ) employed for the conservation of orchid seeds has been explored in a number of studies, and in some cases, this temperature range improved germination (Merritt et al. 2014), as observed in our study. This temperature $\left(-80^{\circ} \mathrm{C}\right)$ was also efficient for seeds storage of Hadrolaelia grandis after periods of 12, 24 and 36 months (Vudala and Ribas 2017). This may have occurred due to changes in the membranes during the freezing process stimulating metabolic pathways to overcome dormancy (Bewley et al. 2012). Mweetwa et al. (2008) found that freezing seeds in a freezer at $-80^{\circ} \mathrm{C}$ increased the germination percentage of Phalaenopsis Sogo Lit-Angel. Freezing and thawing cracked the testa of some orchid seeds, and these cracks eliminated the semipermeable barrier between the testa and the culture media, stimulating germination (Mweetwa et al. 2008). Thornhill and Koopowitz (1992) analyzing the viability of Disa uniflora seeds under storage conditions concluded that below $-70^{\circ} \mathrm{C}$, orchid seeds should retain $50 \%$ viability for a minimum of two centuries, thus allowing genebanking.

The seeds of $G$. recurva, $G$. praetexta, $G$. divaricatum and $G$. forbesii showed high percentages of germination when freshly harvested and they do not present primary dormancy. After one month of storage at $-20^{\circ} \mathrm{C}$ and $-80^{\circ} \mathrm{C}$, the seeds of all species studied showed a decrease in percentage of germination and can have been caused by secondary dormancy. Chilling temperatures can induce secondary dormancy in nondormant seeds, as reported by Geneve (2003). In some cases, seeds that did not require chilling stratification to satisfy primary dormancy may require it for release from secondary dormancy. Intermediate-type seed storage behavior, whereby short periods of storage of dry seeds at subzero temperatures result in dramatically reduced germination, is apparent in some orchid data (Hay et al. 2010, Merritt et al. 2014), as also observed in our study.

The highest percentages of seed germination for all four species were obtained after 12 
months of storage. These results differ from those of Alvarez-Pardo and Ferreira (2006), who described a loss of seed viability for several species, including Trichocentrum pumilum (Lindl.) M.W.Chase and N.H.Williams, after 12 months of storage $\left(-18^{\circ} \mathrm{C}\right)$. However, other species, such as Cyrtochilum flexuosum Kunth, showed no decrease in germination after 12 months of storage at $-18^{\circ} \mathrm{C}$.

In this study, the results of seed viability obtained after germination and tetrazolium test showed differences. These may be due to the pretreatment of $24 \mathrm{~h}$ in $10 \%$ sucrose applied to the seeds submitted to tetrazolium test, which was not carried out on the germinated seeds. Another possibility of the greater viability of the tetrazolium test in comparison with germination test may be due to the surface sterilization protocol, which may have damaged some embryos. The two tests are considered comparable; however, seeds may be dormant or dependent on symbiosis with fungi or environmental signaling (Vujanovic et al. 2000). According to Lauzer et al. (2007), another possibility to explain the different results could be that the nutritional requirements of the seeds were not supplied in the germination medium. Kauth et al. (2008a) evaluating the asymbiotic germination of Calopogon tuberosus (L.) Britton, Sterns \& Poggenb. also reported that the percentage of in vitro germination was lower than that obtained by the tetrazolium test, possibly due to a mechanism of intrinsic dormancy or damage of the embryo during surface sterilization.

\section{CONCLUSION}

The best culture medium composition for the asymbiotic germination for all species studied was WPM, which presented the highest germination percentages and improved seedling development. The seedlings of $G$. divaricatum and G. praetexta were successfully acclimatized using a mixture of vermiculite and Plantmax ${ }^{\circledR}$ as substrate $(3: 1)$. The protocol developed in the present study was efficient for seed bank storage, in vitro germination and seedling production, contributing to a conservation strategy of these species.

Seeds of $G$. divaricatum, $G$. praetexta, $G$. recurva and $G$. forbesii had an orthodox behavior, with high viability rates after 12 months of storage, being recommended the storage temperature of $-80^{\circ} \mathrm{C}$ for the first three species and $-20^{\circ} \mathrm{C}$ for G. forbesii. Although they have presented this orthodox behavior, longer storage times should be tested for its maintenance in seed banks.

In addition, the data obtained from the seed storage of G. divaricatum, G. praetexta, G. forbesii and $G$. recurva will contribute to the Orchid Seed Storage for Sustainable Use project, which is establishing a global network of orchid seed banks in the countries of high biodiversity in Asia and Latin America.

\section{ACKNOWLEDGMENTS}

The authors thank the Coordenação de Aperfeiçoamento de Pessoal de Nível Superior Programa Nacional de Apoio e Desenvolvimento da Botânica (CAPES-PNADB) project for financial support and scholarship awarded to Cristina Batista Franceschi.

\section{AUTHOR CONTRIBUTIONS}

LLFR and ECS designed the project. CRBF carried out the experiments, processed the experimental data, and performed the statistical analysis. LLFR contributed to the design, implementation and supervision of the research, and also to the analysis of the results. CRBF and LLFR wrote the manuscript with support of LNV and ECS. LNV did a critical review and translated the article to english. ECS designed the figure. All authors contributed and approved the final manuscript. 


\section{REFERENCES}

ALVAREZ-PARDO V AND FERREIRA AG. 2006 Armazenamento de sementes de orquídeas. Rev Bras Sementes 28: 92-98.

BEWLEY JD, BRADFORD K, HILHORST H AND NONOGAKI H. 2012. Seeds: physiology of development, germination and dormancy. 3rd ed., Dordrecht: Springer Science \& Business Media, 381p.

BONGA JM. 1985. Tissue culture techniques. In: Bonga JM and Durzan D (Eds), Tissue Culture in Forestry. Dordrecht: Martinus Nijhoff, p 4-35.

CARDOSO JC, TEIXEIRA DA SILVA JÁ AND VENDRAME WA. 2016. Impacts of deforestation on some orchids of São Paulo State, Brazil. Nat e Conserv 14: $28-32$.

CHUGH S, GUHA S AND RAO IU. 2009. Micropropagation of orchids: a review on the potential of different explants. Sci Hortic 122: 507-520.

FAY MF. 2016. Orchid conservation: further links. Ann Bot 118: 89-91.

FLORA DO BRASIL 2020 IN CONSTRUCTION. n.d. Jardim Botânico do Rio de Janeiro. [WWW Document]. URL http://floradobrasil.jbrj.gov.br/reflora/floradobrasil/ FB179 (accessed on 4.4.17).

GENEVE RL. 2003. Impact of temperature on seed dormancy. HortScience 38: 336-341.

HAY FR, MERRITT DJ, SOANES JA AND DIXON KW. 2010. Comparative longevity of Australian orchid (Orchidaceae) seeds under experimental and low temperature storage conditions. Bot J Linn Soc 164: 26-41.

HIGASHIKAWA FS, SILVA CA AND BETTIOL W. 2010. Chemical and physical properties of organic residues. $\mathrm{R}$ Bras Ci Solo 34: 1743-1752.

HOSOMI ST, CUSTÓDIO CC, SEATON PT, MARKS TR AND MACHADO-NETO NB. 2011. Preconditioning Cattleya seeds to improve the efficacy of the tetrazolium test for viability. Seed Sci \&Technol 39: 178-189.

HOSOMI ST, CUSTÓDIO CC, SEATON PT, MARKS TR AND MACHADO-NETO NB. 2012. Improved assessment of viability and germination of Cattleya (Orchidaceae) seeds following storage. In Vitro Cell Dev Biol - Plant 48: 127-136.

IUCN/SSC ORCHID SPECIALIST GROUP. 1996. Orchids: status survey and conservation action plan. IUCN, Gland Switzerland and Cambridge, UK.

KAUTH PJ, DUTRA D, JOHNSON TR, STEWART SL, KANE ME AND VENDRAME WA. 2008b. Techniques and applications of in vitro orchid seed germination. In: Teixeira da Silva JA (Ed), Floriculture, ornamental and plant biotechnology: advances and topic issues. Isleworth: Global Science Books, p. 375-391.
KAUTH PJ, KANE ME, VENDRAME WA AND REINHARDT-ADAMS C. 2008a. Asymbiotic germination response to photoperiod and nutritional media in six populations of Calopogon tuberosus var. tuberosus (Orchidaceae): Evidence for ecotypic differentiation. Ann Bot 102: 783-793.

KLEIN VA, SIOTA TA, ANESI AL AND ROBINSON B. 2000. Propriedades físico-hídricas de substratos hortícolas comerciais. Rev Bras Agrociênc 6: 218-221.

KNUDSON L. 1946. A new nutrient solution for germination of orchid seed. Am Orchid Soc Bull 15: 214-217.

LAUZER D, RENAUT S, ST-ARNAUD M AND BARABÉ D. 2007. In vitro asymbiotic germination, protocorm development, and plantlet acclimatization of Aplectrum hyemale (Muhl. ex Willd.) Torr. (Orchidaceae). J Torrey Bot Soc 134: 344-348.

LLOYD G AND MCCOWN BH. 1980. Commerciallyfeasible micropropagation of mountain laurel, Kalmia latifolia, by use of shoot-tip culture. Proc Int Plant Propagators' Soc 30: 421-427.

MERRITT DJ, HAY FR, SWARTS ND, SOMMERVILLE KD AND DIXON KW. 2014. Ex situ conservation and cryopreservation of orchid germplasm. Int J Plant Sci 175: 46-58.

MORAES L, CAVALCANTE L AND FARIA R. 2002. Substratos para aclimatização de plântulas de Dendrobium nobile Lindl. (Orchidaceae) propagadas in vitro. Acta Sci Agron 24: 1397-1400.

MUÑOZ MAND JIMÉNEZ VM. 2008. Capsule development, in vitro germination and plantlet acclimatization in Phragmipedium humboldtii, $P$. longifolium and $P$. pearcei. Lankesteriana 8: 23-31.

MURASHIGE T AND SKOOG F. 1962. A revised medium for rapid growth and bio assays with tobacco tissue cultures. Physiol Plant 15: 473-497.

MWEETWAAM, WELBAUM GEAND TAY D. 2008. Effects of development, temperature, and calcium hypochlorite treatment on may have been caused by secondary dormancy in vitro germinability of Phalaenopsis seeds. Sci Hortic 117: 257-262.

PAN MJ AND VAN STADEN J. 1998. The use of charcoal in in vitro culture - A review. Plant Growth Regul 26: 155163.

PEBAM B, KISHOR R AND NARMATHA BAI V. 2016. In vitro immature embryo germination and propagation of Vanda stangeana Rchb. f., an orchid endemic to India. Hortic Environ Biotechnol 57: 615-624.

PIRIA RS, RAJMOHAN K AND SURESH S. 2008. In vitro production of protocorms and protocorm like bodies in orchids - a review. Agric Rev 29: 40-47.

RASMUSSEN HN, DIXON KW, JERSÁKOVÁ J AND TĚŠITELOVÁ T. 2015. Germination and seedling 
establishment in orchids: a complex of requirements. Ann Bot 116: 391-402.

RIBEIRO MC, METZGER JP, MARTENSEN AC, PONZONI FJ AND HIROTA MM. 2009. The Brazilian Atlantic Forest: How much is left, and how is the remaining forest distributed? Implications for conservation. Biol Conserv 142: 1141-1153.

ROY AR, PATEL RS, PATEL VV, SAJEEV S AND DEKA BC. 2011. Asymbiotic seed germination, mass propagation and seedling development of Vanda coerulea Griff ex.Lindl. (Blue Vanda): An in vitro protocol for an endangered orchid. Sci Hortic 128: 325-331.

SAAD AIM AND ELSHAHED AM. 2012. Plant Tissue Culture Media. In: Leva A and Rinaldi LMR (Eds), Recent Advances in Plant in Vitro Culture, Winchester: InTech, p. 29-40.

SANTOS SA, SMIDT EC, PADIAL AA AND RIBAS LLF. 2016. Asymbiotic seed germination and in vitro propagation of Brasiliorchis picta. Afr J Biotechnol 15: 134-144.

SEATON P, KENDON JP, PRITCHARD HW, PUSPITANINGTYAS DM AND MARKS TR. 2013. Orchid conservation. Lankesteriana 13: 93-101.

SEATON P AND RAMSAY M. 2005. Growing orchid from seed, 1st ed., Richmond: Royal Botanic Garden, 83 p.

SEATON PT, HU H, PERNER H AND PRITCHARD HW. 2010. Ex situ conservation of orchids in a warming world. Bot Rev 76: 193-203.
STEWART SL AND KANE ME. 2006. Asymbiotic seed germination and in vitro seedling development of Habenaria macroceratitis (Orchidaceae), a rare Florida terrestrial orchid. Plant Cell Tissue Organ Cult 86: 147-158.

SUZUKI RM, MOREIRA VC, PESCADOR R AND FERREIRA WDM. 2012. Asymbiotic seed germination and in vitro seedling development of the threatened orchid Hoffmannseggella cinnabarina. In Vitro Cell Dev Biol Plant 48: 500-511.

SWARTS ND AND DIXON K. 2009. Terrestrial orchid conservation in the age of extinction. Ann Bot 104: 543-556.

THOMAS TD. 2008. The role of activated charcoal in plant tissue culture. Biotechnol Adv 26: 618-631.

THORNHILL A AND KOOPOWITZ H. 1992. Viability of Disa uniflora Berg (Orchidaceae) seeds under variable storage conditions: Is orchid gene-banking possible? Biol Conserv 62: 21-27.

VACIN F AND WENT FW. 1949. Some pH changes in the nutrient solutions. Bot Gaz 110: 605-613.

VUDALA SM AND RIBAS LLF. 2017. Seed storage and asymbiotic germination of Hadrolaelia grandis (Orchidaceae). S African J Bot 108: 1-7.

VUJANOVIC V, ST-ARNAUD M, BARABÉ D AND THIBEAULT G. 2000. Viability testing of orchid seed and the promotion of colouration and germination. Ann Bot 86: 79-86. 